Texas A\&M University-San Antonio

Digital Commons @ Texas A\&M University-San Antonio

Criminology and Criminal Justice Faculty

Publications

College of Arts and Sciences

2-2015

Building Legal Competency: Foundations for a More Effective

Criminology and Criminal Justice Discipline

Claire Nolasco

Rolando V. del Carmen

Kevin F. Steinmetz

Michael S. Vaughn

Aneta Spaic

Follow this and additional works at: https://digitalcommons.tamusa.edu/crim_faculty

Part of the Criminology and Criminal Justice Commons 


\title{
BUILDING LEGAL COMPETENCY: FOUNDATIONS FOR A MORE EFFECTIVE CRIMINOLOGY AND CRIMINAL JUSTICE DISCIPLINE
}

\author{
Claire Angelique R. I. Nolasco, J.D., Ph.D. ${ }^{+}$ \\ College of Arts and Sciences \\ Department of Criminology \\ Texas A\&M-San Antonio \\ One University Way \\ San Antonio, TX 78224 \\ Tel. 210.784.2210 \\ claire.nolasco@tamusa.tamus.edu \\ Rolando V. del Carmen, J.D., S.J.D. \\ College of Criminal Justice \\ Institute for Legal Studies in Criminal Justice \\ Sam Houston State University \\ Huntsville, TX 77341-2296 \\ $81617^{\text {th }}$ Street \\ P.O. Box 2296 \\ Tel: 936.294.1656 \\ icc_rvd@shsu.edu \\ Michael S. Vaughn, Ph.D. \\ College of Criminal Justice \\ Institute for Legal Studies in Criminal Justice \\ Sam Houston State University \\ Huntsville, TX 77341-2296 \\ $81617^{\text {th }}$ Street \\ P.O. Box 2296 \\ Tel: 936.294 .1349 \\ mvaughn@shsu.edu \\ Kevin F. Steinmetz, Ph.D. \\ Assistant Professor \\ Department of Sociology, Anthropology, and Social Work \\ Kansas State University \\ kfsteinmetz@ksu.edu \\ Aneta Spaic, Ph.D. \\ Assistant Professor, Faculty of Law \\ University of Montenegro \\ Podgorica, Montenegro \\ Tel: +38240481141 \\ anetaspaic@gmail.com
}

${ }^{+}$Corresponding author 


\section{BUILDING LEGAL COMPETENCY: FOUNDATIONS FOR A MORE EFFECTIVE CRIMINOLOGY AND CRIMINAL JUSTICE DISCIPLINE}

\section{INTRODUCTION}

Criminology and criminal justice, although a relatively new field in the social sciences, is maturing and reaffirming itself as a rigorous academic discipline. The depth of the discipline has been further established through research and literature in the various areas of theory, methods, scope, and the discipline's status as a field of knowledge. From the growing number of professional conferences and associations to the proliferation of doctoral programs and journals, criminology and criminal justice is becoming more academically firm—shaking off the stigma from earlier decades of being too "vocational" and coming into its own as a legitimate scientific discipline. The focus on theory, policy, research methodologies, and various analytic approaches has led, however, to a marginalization of areas that were once core to the discipline. Qualitative research methodologies and legal studies, for example, appear to have been cast aside in favor of more quantitative methods that are prevalent in social science (Nolasco, Vaughn, \& del Carmen, 2010).

This article suggests that the marginalization of law and legal courses from other areas of discussion and research in criminal justice or criminology has hindered its full development in criminology and criminal justice doctoral programs. This marginalization is reflected in the hesitance of departments to hire non-law trained academics to teach law courses and doctoral students to take courses that require immersion and knowledge in law. Myers (2007, p. 5) illustrates the need for legal competency in the discipline, stating that, 
[i]f it is a law course, I do not know too many Ph.D.'s who are qualified. Some doctoral programs require legal courses and require students to pass a legal comprehensive exam. I do not believe even those Ph.D.s are truly qualified to teach legal courses to students because they do not have the extensive knowledge held by the J.D. Unfortunately, some of these legally trained Ph.D.s do not selfreflect enough to acknowledge they are not prepared as their legal counterparts to teach these courses.

This article further demonstrates how legal competency is necessary and contributes towards a more effective and relevant academic discipline. Adequate legal training within the program can effectively prepare criminology and criminal justice doctoral students to undertake both legal and socio-legal research and possibly, teach law courses as a competency in their academic path.

\section{Background}

Studies that focus on marginalized areas in the discipline, including disciplinary disputes, are nothing new in criminal justice and criminology (Clear, 2001; Conrad \& Myren, 1979; DiCristina, 1997; Green, Bynum, \& Webb, 1982; Morn, 1980; Nolasco, Vaughn, del Carmen, 2010; Simpson, 1979; Steinmetz, Schaefer, del Carmen, \& Hemmens, 2014; Worrall, 2000; Wrede \& Featherstone, 2012; Zalman, 1981). Such works are undoubtedly symptomatic of the discipline's growing pains and are not unique to criminal justice and criminology. These studies are important because they provide an insight into issues that otherwise are left unexamined. From early debates within the Joint Commission for Criminology and Criminal Justice Education and Standards (hereby referred to as The Commission) over the boundaries between criminal justice and 
criminology (Conrad \& Myren, 1979; Green, et al., 1982; Morn, 1980; Simpson, 1979;

Zalman, 1981) to efforts to distinguish criminal justice and criminology as a discipline separate from sociology (Wrede \& Featherstone, 2012), these studies are valuable in articulating issues as well as providing a venue for open debate and discussions that help define the boundaries of the discipline.

Revisiting some of these issues and expanding on this body of critiques, this article posits that although there is a growing demand for legal competency in criminal justice and criminology doctoral programs, law is still currently viewed as an isolated field of knowledge, lacking relevance to the discipline. This has resulted in "dichotomous debates of the J.D. versus the Ph.D. and criminology versus criminal justice" (Myers, 2007, p.1). As of 2012, out of 36 doctoral programs listed by the Association of Doctoral Programs in Criminology \& Criminal Justice, 19 programs (52.78\%) required classes that claimed to study law or its legal aspects within criminal justice to some degree. These courses range from those which focus on the sociology of law ${ }^{1}$ to black letter law ${ }^{2}$. In this study, the authors analyzed course descriptions to determine whether a course focused on law. If we consider, however, that at least some of these classes focus only tangentially on legal issues or the sociology of law, it becomes apparent that the effort to

\footnotetext{
1"The sociology of law, a new science, studies human behavior in society in so far as it is determined by commonly recognized ethico-legal norms, and in so far as it influences them" (Timasheff, N.S. (1937). What is "sociology of law"? American Journal of Sociology, 43, 225-235).

2"Black Letter Law refers to the basic standard elements or principles of law, which are generally known and free from doubt or dispute. It describes the principles of law that are accepted by a majority of judges in most states. For example, it can be the standard elements for a contract or the technical definition of assault. In American legal system, it also means well-established case law" (USlegal.com (2014). Definition of black letter law. Retrieved from http://definitions.uslegal.com/b/black-letter-law/. "The systematization and formulation of the law in terms of doctrine creates a conceptual basis for constructing a legal context that helps to determine which rules should be applied in a particular situation. In this sense, doctrinal studies emerge out of the study of legal texts (or black-letter law), which are generated by legislature, courts and other legal authorities, and feed back in to legal practice once they are used in deciding cases" (Banakar, R. (2011). Review essay: Having one's cake and eating it: The paradox of contextualization in socio-legal research. International Journal of Law in Context, 7, 487-503).
} 
develop legal competency is lacking in doctoral programs. This is happening in a discipline that is supposed to study the crimino-legal apparatus in addition to other areas such as criminal etiology.

An examination of the origins of the discipline reveals an intention among early scholars in the field to emphasize the importance of law and legal knowledge, particularly criminal law and related legal studies. From its early beginnings, legal competency, contrary to being marginalized in criminal justice and criminology, was an integral part of criminal justice and criminology. Edwin Sutherland (1924), the noted father of criminology, required his criminology students to minor in criminal law. Quinney (1970) acknowledged that to understand crime, one must consider how criminal law shapes crime:

There is no crime without some form of declaration. Crime has meaning only when the concept of crime has first been constructed. Likewise, crime exists as a problem only when a number of persons regard the phenomenon of crime as a problem. Crime as both phenomenon and problem thus exists because of the construction of the concept of crime. (Quinney, 1970, p. 3)

Recent studies in the discipline, however, tend to dissociate itself from social and legal constructions of crime by focusing not on crime as a dependent variable but on the broader notion of anti-social behavior (Eitle, Niedrist, \& Eitle, 2014; Jennings, Higgins, Akers, Khey, \& Dobrow, 2013; Newton \& Bussey 2012; Portnoy, Raine, Chen, Pardini, Loeber, \& Jennings, 2014). Setting aside arguments on the notion and construction of anti-social behavior, criminal justice and criminology cannot completely dissociate itself from examining and explaining crime as a legal and social construction (Quinney, 1970). To 
do so denies the nature of crime, in its formal reality, as a product of law. As such, scholars of criminal behavior should be properly trained in the nuances of criminal law and criminal procedure to inform their behavioral and social analyses (Kelman, 2003; Wexler, 1990). To understand a phenomenon, one must know why it exists. In a formal and realistic sense, there is no crime without a law. What is criminal becomes immoral, deviant, aberrant, or irritant behavior.

The deemphasis in criminal law and law courses may have first emerged due to efforts of scholars in criminal justice and criminology to achieve the status of a legitimate and scientific discipline in the 1970s and 1980s. This followed the influx of LEAA funding that sought to promote the professionalization of the police through college education (Conrad \& Myren, 1979; Green, et al., 1982; Morn, 1980; Simpson, 1979; Zalman, 1981). These efforts often distinguished between the academic and vocational faces of the discipline. In the mix, education in criminal law and criminal procedure was considered too practitioner-oriented. This article argues that law is a legitimate area of academic inquiry and training and thus deserves to be required as an integral part of Ph.D. program in criminal justice and criminology (Nolasco, et al., 2010).

As a discipline, we have certainly not outgrown the need to consider law in research and education. While much of the research in criminal justice and criminology has focused on the impact of various social structural and cultural forces on various criminal justice system outcomes, there persists a need to look at the effect and impact of legal factors. David Garland's (2013) 2012 Sutherland Address to the American Society of Criminology stressed the need to consider this factor:

The second consideration has to do with a sociological bias that has shaped our 
causal analyses. Until now, the punishment and society literature has concentrated on what one might term 'deep' or background causation: the kinds of cultural, political, and economic processes that I discussed previously. But this is only half the story. We should recognize that the proximate causes of changing patterns of punishment lie not in social processes but in state and legal processes: chiefly in legislative changes made to sentencing law and in the actions of legal decision makers such as prosecutors, sentencing judges, corrections departments, and parole boards pursuant to these legal changes. (Garland, 2013, p. 484)

If the discipline is to properly study these "state and legal process" then its future scholars-Ph.D. students—must develop legal competency through adequate understanding of the role of law in deciding what is criminal and how punishment can and should be meted out justly.

Doctoral programs should also include training in black letter law because more stringent academic hiring standards in the discipline in general show preference for doctorate degrees (Ph.D.) over Juris Doctorates (J.D.s). In academe, J.D.s are not considered terminal degrees, and there are compelling reasons why they should not be given equal weight as Ph.D.s in social science (Hemmens, 2008). The training required for J.D.s are not tailored toward the demands of social science scholarship and research. As a result, many criminal justice and criminology programs prefer graduates with Ph.D. qualifications in their faculty. While this may be laudable, it also means that persons trained mainly in law, such as a candidate with a J.D., are less likely to be hired as a tenured faculty. 
Examination of the tenure track faculty vacancy announcements on HigherEd Jobs as of 5 June 2014, reveal that out of 46 postings, Criminology and Criminal Justice programs prefer specializations in the following areas: corrections (7\%), generalist (16\%), juvenile delinquency (5\%), law enforcement (16\%), law (16\%), open (24\%), research methods (9\%), and theory (7\%). The demand for applicants with specialization in law (criminal law, criminal procedure, courts, substantive and procedural law) is considerable, constituting $15 \%$ of the job postings-as much as the demand for applicants who are generalists and who have law enforcement areas of concentration. To satisfy both the desire to be a Ph.D. dominated faculty while also including robust education and research in law, there is a clear need to develop legal competency among Ph.D. graduates, including training in black letter law.

There are reasons why legal competency is desirable and needed in criminal justice and criminology. Five propositions help reaffirm the benefits that doctoral legal competency provides the discipline:

\section{Proposition 1: LEGAL COMPETENCY HELPS ENABLE PH.D. GRADUATES CONDUCT} SCHOLARLY RESEARCH IN LAW RELATED TOPICS. The research field in "law in criminal justice" is vast and largely unexplored, particularly in the administrative and operational phases of criminal justice. For example, two of the current concerns in criminal justice are eyewitness misidentification partly resulting from media hype and the use or misuse of force by the police. These are not theoretical dilemmas, but are instead real, recurring, and day-to-day concerns among practitioners and the public. Research in "law in criminal justice" on these topics is best done by Ph.D. graduates familiar with quantitative research 
methods, rather than by lawyers bereft of quantitative skills. Research on these issues, however, requires legal competency, based on knowledge and understanding of current law and agency practices.

Quantitative legal research is largely an underdeveloped tool at a time when quantification has become normative in just about any social science discipline. This deemphasis in quantitative legal research may be traced to legal research being done by lawyers who do not much background in statistics or quantification. It is impractical to give lawyers extensive background in quantitative methods since law is a specialized field and advocacy driven. Lawyers have more practical concerns that do not require quantification. A better option would be to enhance the legal competency of criminal justice Ph.D. students to better equip them with skills that can help shed light on legal issues inherent in criminal justice and criminology.

Legal studies in the discipline can also contribute to determining legal outcomes and their validity, employing social science research methods along with legal research methods. Scholarly research can potentially lower bias in case outcomes because these are empirically tested and rely on systematically collected data, use accepted methodological standards to analyze the results, undergo a rigorous peer review process by experts in the field, are subject to replication, and hence, are both testable and validated (Grunwald, 2013). Thus, scholarly research, when properly presented and admitted in court, may counter a judge's "potentially false perception" of social science data, persuade the judge that his or her "empirical intuition" may be inaccurate, and "increases transparency of judicial decisions" (Grunwald, 2013, pp. 1432-1433). 
Legal research in criminal justice and criminology, for example, may prove invaluable during trial (Monahan \& Walker, 1991), as these may be presented as "social authority" (Monahan \& Walker, 1986, p. 488). Monahan and Walker (1986) recommend that courts rely on research that has "survived the critical review of the scientific community, is based on valid methodology, generalizable to the case at hand, and confirmed by a larger body of research" (Monahan \& Walker, 1986, p. 489). Walker and Monahan (1987, pp. 568-570, 559) suggest that scholarly research can provide the "social framework" or background context of a particular factual issue in a legal case that "helps the factfinder interpret the validity and relevance of adjudicative facts presented before the court." In State v. Chapple (1983), for example, a defendant charged with murder based on eye witness testimony attempted to introduce expert testimony to show that the identification process was not reliable. The defense introduced in evidence social science research on the unreliability of eyewitness identification (Grunwald, 2013). This can make the crucial difference in a decision.

Scholarly legal research on criminal justice issues can further potentially reduce bias in case outcomes arising from the judge's personal experiences or unguided empirical observations (Epstein \& King, 2002; Grunwald, 2013; Kahan, Jenkins-Smith, \& Braman, 2011; Leonard, 2002; Meares, 2002). Legal scholars have noted the relationship between political beliefs and judicial decision-making in environmental and administrative case law (Cross \& Tiller, 1998; Landes \& Posner, 2009; Perino, 2006; Revesz, 1997; Sisk \& Heise, 2005; Sunstein, Schkade, Ellman, \& Sawicki, 2006). One study showed that when decisions of the Environmental Protection Agency were challenged before the courts, "the reversal rate for panels with two Democrats and one Republican" ranged from $2 \%$ to $13 \%$ as 
opposed to panels with "two Republicans and one Democrat" where the reversal rate ranged from $54 \%$ to $89 \%$ (Revesz, 1997, p. 1763). Another study found that among D.C. circuit cases reviewing an administrative law under Chevron U.S.A.v. Natural Res. Def. Council, Inc. (1984), when the agency's policy outcome is "consistent with the policy preferences of the panel majority," the court is $31 \%$ more likely to defer than if it does not (Cross \& Tiller, 1998, p. 2171).

\section{Proposition 2: PH.D. CRIMINOLOGY AND CRIMINAL JUSTICE GRADUATES WITH}

\section{LEGAL TRAINING ARE BETTER PREPARED TO TEACH LAW AS A PHENOMENON}

RELATED TO SOCIAL REALITY. Law schools, steeped in doctrinal legal teaching and research do not, in general, teach social facts and social reality as empirical phenomenon (Berard, 2009; Samuel, 2008). Law schools do not study the contexts of legal practice. For example, there are few courses in law schools that focus on "law firms, corporate counsel's offices, or government lawyering” (Rubin, 2007, p. 642). Social sciences such as criminal justice and criminology, by learning and offering courses in areas of law relevant to their disciplines, can analyze, test, and examine law and legal phenomenon as a social reality (Birks, 1998; Lawless, Robbennolt, \& Ulen, 2009; Siems, 2011).

Limitations of existing law studies have been recognized by jurists and legal scholars. Legal academics point out the dearth of research in law as a social and empirical phenomenon within the context of social institutions (Bradney, 1998). Cotterrell (1995, p. 296) observed that "all the centuries of purely doctrinal writing on law have produced less valuable knowledge about what law is, as a social phenomenon, and what it does than the relatively few decades of work in sophisticated modern empirical socio-legal studies." 
Hepple (1996, p. 485), in his inaugural lecture at Cambridge University, noted that law students should study among other things "social sciences, philosophy, ethics, history," and have the "ability to comprehend evidence and methods of social sciences." Bradney (1998, p. 79) espouses a broader form of legal studies that he terms "socio-legal studies" in order to promote wider learning within the context of the community. Socio-legal studies will enhance knowledge of the law in three ways: first, while doctrinal legal studies prohibit inquiries outside the legal context of laws and its authorities, socio-legal studies encourages and facilitates them; second, by engaging in other disciplines, the student will have to "enter into the communities that constitute the discipline and embrace its values;" and third, by engaging other disciplines, students are able to pursue learning and research not constrained by the "limits of one discipline" but by a mix of different disciplines of their own choosing (Bradney, 1998, pp. 79-80).

Given the focus on traditional doctrinal research in law schools, legal education has perennially faced the issue of the status of law in academe and whether it should be considered a social science or a natural science akin to mathematics (Grey, 1983; Rubin, 2007; Schweber, 1999). Christopher Langdell, Dean of Harvard Law School who first introduced the casebook method of legal education viewed law as a form of natural science with its own coherent and logical structure (Chase, 1979; Rubin, 2007; Samuel, 2008). Legal education therefore should use the same approach as the natural sciences, through "inquiry that would disclose its principles," by studying the law's particular manifestations "just as the natural scientist could discern the universal law of gravitation by observing the behavior of specific falling objects" (Rubin, 2007, p. 632) 
Samuel (2008, p. 294) states that one argument against law as a social science is "grounded in [law's] quest for a natural science status," specifically akin to mathematics, a non-empirical scientific discipline "where the test is one of coherence rather than correspondence." Traditional legal studies, with its emphasis on the coherence and consistency of doctrines and legal authorities (e.g. statutes, cases, and customs) aim to elevate law to scientific inquiry, analogous to mathematics with its coherent system of formulas and solutions (Nolasco, et al., 2010). Law has become pre-occupied with its "own internal organization" that, as an academic discipline, it has "completely isolated itself from social reality" (Samuel, 2008, p. 295).

Distinctions have been made between doctrinal legal studies and comparative legal studies (Nolasco, et al., 2010; Samuel, 2008). Most law schools, for example, rely mainly on doctrinal analysis and the Socratic method of instruction (Berard, 2009; Bradney, 1998). Samuel (2008) argues that doctrinal legal studies are not a social science because it does not attempt to contribute knowledge to social reality as an empirical phenomenon. Legal education is thus limited in its capacity to study the "complexity and importance of the relations between law and society" or to understand social scientific perspectives on the law (Berard, 2009, p. 191). Comparative legal studies, however, "deserves to qualify as a social science" because of its potential to examine law from outside the paradigm of legal authorities internal to law as a discipline (Samuel, 2008, p. 321). Samuel (2008, pp. 319, 320) cautions that comparative legal studies, "if it is to make a serious contribution to knowledge in general, must employ comparison as an epistemological tool" beyond the framework of the "traditional internal doctrinal methodology." 
Although doctrinal analysis focuses on legal concepts and doctrines inductively or deductively, as extracted from law and cases, such method does not denote complete isolation from social reality or from empirical examination of facts. Law students examine facts, evidence, and empirical data. After learning legal rules and doctrines, a law student must be able to analyze social reality in the form of facts of the case to be able to interpret the applicability of certain doctrines to the factual situation. A general handicap of law students is their inability to analyze factual situations systematically (beyond the current case) so as to be able to draw statistical conclusions as is common in the social sciences. That is not in their training. Law students are more often taught to examine one factual situation at a time or resort to landmark cases or authorities to support legal reasoning. They are not trained to explain facts as social reality; instead, they are trained to use the facts to draw legal conclusions.

It is because of this limitation in law studies that the social sciences can effectively complement legal knowledge. Social scientists aim to study society and social facts at various levels of analysis as empirical data. Criminal justice and criminology students have the background that enables them to extract facts from a pool of cases that discuss a specific legal area of concern, as well as to systematize, and analyze such facts using social scientific statistical methods. If law students are indeed limited to a traditional doctrinal analysis of legal authorities, then criminal justice and criminology students are potentially able to contribute knowledge to law as a social reality. Consider, for example, the current and controversial issue in some major cities of the legality of strip searches. Going beyond a doctrinal legal analysis, social scientists can examine the factual basis of a pool of cases (extracted from legal databases such as Lexis-Nexis or Westlaw) that influenced the courts' 
decisions on whether or not to uphold it. Such factual analysis can focus on a variety of factors such as socio-demographic individual variables of the person subjected to the strip search, contextual variables such as location, time, length, and intrusiveness of the search, and geographic variables such as region, district, city, or area of the search. All these factors can then be analyzed to determine the likelihood of the courts deciding in favor or against the legality of the search based on the cases.

Because of the technical nature of legal documents and the precise nature of legal research, knowledge of the law and legal research is central to this exercise by social scientists. By offering law courses in the social sciences, students are equipped with knowledge of the law (including case law), legal research and methodology, and legal academic writing. Leighton, Mortimer, and Whatley (1995) point out another compelling reason for teaching law to undergraduate criminal justice and criminology students. Their 1994 survey of the work of legal academics found that 92 percent of all legal academics they surveyed preferred to teach either College of Law or law postgraduates to any other type of student, because the latter involves, "teaching law to non-lawyers" (Skwarok, 1995, p. 189) thus, implying a secondary or inferior type of teaching (Leighton, et al., 1995, p. 34). Students outside law school have little opportunity to study law since law courses are either absent from, or offered only as a small part of their disciplines. This prevents them from obtaining a "real understanding of legal concepts" as well as the subtleties of legal analysis (Ridley, 1994, p. 284). Thus, it is incumbent upon criminal justice and criminology departments to offer law courses, whether doctrinal, socio-legal, or comparative law; it remedies a deficiency in the field. 
Several reasons justify offering law courses to non-law students, including criminal justice and criminology doctoral students. Harris (1986, p. 112) argues that, "empirically, law is a component part of the wider social and political structure, is inextricably related to it in an infinite ways, and can therefore only be properly understood in that context." The benefits of teaching law outside traditional confines have also been noted in several areas. Teaching law to accountancy students, for example, resulted in a 6 percent rise in those students who "definitely saw law as being relevant to their studies" (Ridley, 1994, p. 283). Cartan and Vilkinas (1990, p. 248) further found that teaching law to managers enabled them to view law as a "living entity which has a future as well as a present and recognizes law as an evolving process with important elements of history, sociology, politics, and economics." Students outside of law school must "see the place that law has in the object of their study," to properly understand the wider social and political structure of which law is merely a component, albeit an essential one (Bradney, 1998, p. 83). Within the discipline of criminal justice and criminology, the teaching of law must be made relevant to the study of the objects of the discipline (i.e., crime or anti-social behavior and the criminal justice system). If law is to be learned as a tool for understanding a social phenomenon, then it is best taught by those trained in this approach rather than by those trained as advocates of opposing sides in a two-sided conflict.

\section{Proposition 3: THERE IS AN INCREASING TREND TOWARD INTERDISCIPLINARY STUDIES AND INTERDISCIPLINARY APPROACHES IN ACADEMIC DISCIPLINES,}

INCLUDING LAW. Interdisciplinary studies such as law conjoined with areas like economics (Korobkin, 2014; Marciano \& Ramello, 2014), medicine (Madden \& Wayne, 
2003; Preston-Shoot \& McKimm, 2011), history (Rubin, 2007; Samuel, 2012), political science, society, and sociology (Schluchter, 2002) have spurred the growth of more empirically based research on the law and its various institutions (Bartie, 2010; Bradney, 1998; Cownie, 2004; Kennedy \& Fisher, 2006; Macey, 1997; Shaffer \& Ginsburg, 2012;

Siems \& MacSithigh, 2012). Distinctions, however, should be made between interdisciplinary approaches to law that use the social science methodology and those that do not (i.e., interdisciplinary approaches based on feminism, critical race theory or critical legal studies) (Bradney, 1998; Macey, 1997; Siems \& MacSithigh, 2012). A multidisciplinary legal approach that uses empirically based social sciences methodology can increase its impact and promote a greater level of intellectual discourse among a wider audience of scholars outside of the legal community (Epstein, Martin, \& Boyd, 2007; Epstein, Martin, \& Schneider, 2006; Macey, 1997). Thus, socio-legal studies that develop testable hypotheses and assertions about the law are "empirically refutable" and more convincing than interdisciplinary approaches to law that do not rely on the social sciences, such as the critical race approach or those based on feminism (Macey, 1997, p. 172).

The increasing body of social scientific studies of law and legal institutions in the social sciences (Tait \& De Young, 2000) is paralleled by efforts to increase social science instruction in law schools (Bybee, 2004; Berard, 2009; Chemerinsky, 2008; Wexler, 1990). Reforms in legal education, for example, call for an interdisciplinary legal pedagogy that includes exposure of law students to social science methodology, including statistics (Johnstone, 1992; Morris, 2005; Stevens, 1983; Wexler, 1990). Chemerinsky (2008, pp. 597-598), Founding Dean of the University of California Irvine Law School, observes that, "law is inherently interdisciplinary and must be shaped by understanding fields such as 
economics, philosophy, and psychology." He lamented that, law schools "still do too little to bring these disciplines into their classes in a systematic way" and do not make any "coordinated efforts" to ensure "interdisciplinary instruction" in the curriculum (Chemerinsky, 2008, pp. 597-598). He also admonished his colleagues to rethink legal education by becoming more interdisciplinary, and providing students with the "knowledge and perspectives" that come from social science disciplines such as economics, sociology, philosophy, and psychology (Chemerinsky, 2008, p. 598).

Other law academics also propose a broader legal education that addresses law in its totality, by examining not only the black letter of the law but also the non-legal context of legal issues (Eisenmann, 1973; Manning, 1969; Packer \& Ehrlich, 1972). Manning (1969) suggests that non-legal considerations are relevant in examining the social processes within which law functions, including the economic and political settings of law and legal institutions. Packer and Ehrlich (1972, p. 60) similarly propose that law be taught as a "social process," focusing the law student's attention on the conception of the legal system, various legal actors and institutions and their functions, their impact on other elements in society, and changes in the legal system. Wilkins (1999, pp. 79-80), on the other hand, calls for "systematic and rigorous" quantitative and qualitative research on the legal profession's institutions, organizations, norms, and practices.

With this increasing multidisciplinary reform in legal education, criminal justice and criminology stand to benefit from building legal competency among its graduates through incorporating law courses in the graduate curriculum, whether as black letter law, sociology of law, or law and society. Social science scholarship can contribute to legal education through its use of empirical research methods in "gathering evidence or 
assessing claims, to illuminating such questions as the impacts of law on clients and society" (Berard, 2009, p. 211). Duxbury (2003) asserts that the law and society movement has made important contributions in examining how law operates within a social context beyond what can be gleaned from the study of strictly black letter law. The social sciences can contribute to legal studies by providing more comprehensive and systematic knowledge of the practical realities of law, its institutions, and the legal profession (Banakar, 2011).

The value of law courses in criminal justice and criminology cannot be overemphasized. Law schools at present are not currently staffed to teach the full range of legal courses that go beyond traditional doctrinal analysis (Berard, 2009; Trubek \& Plager, 1985). Berard (2009, p. 200) observes that law students have a "much better chance" of receiving interdisciplinary education "either by continuing reforms within law schools, or by engaging in interdisciplinary studies which partly or completely step outside the law school curriculum into other available institutions and disciplines." Reforms include hiring law faculty members with social science credentials, offering more social science electives in law schools either during the first year of law studies or as required courses, requiring an upper-class curriculum that offers students the opportunity to concentrate in one area of specialization that goes beyond the mastery of legal rules and incorporates the substance of social sciences in the courses, offering more joint degree or multi-disciplinary programs, and increasing resources for law faculty through providing them with more pedagogical social science materials (Berard, 2009; Rubin, 2007).

In the social sciences, familiarity with and understanding of law can further enhance legal studies and vice versa. Precisely because social sciences incorporate social theory and 
social research methods, disciplines such as criminal justice and criminology are better positioned to study law as social phenomenon and not just as a statutory mandate or legal precedent. Interdisciplinary approaches in the social sciences are not unusual and the various disciplines have in fact been enriched by multidisciplinary approaches to the study of social reality. Criminal justice and criminology can benefit more from such incorporative practices. An interdisciplinary focus has been one of the greatest strengths of the discipline. As Clear (2001, p. 711) has stated, "We are multidisciplinary always, interdisciplinary at our best."

\section{Proposition 4. PROFESSORS WITH BACKGROUND MAINLY IN LAW ARE NOT TRAINED TO CRITIQUE AND QUESTION DOCTRINAL LAW. THUS, EFFORTS TO REFORM CRIMINAL JUSTICE LAWS ARE NIGGARDLY RESEARCHED OR ADVOCATED.} As a discipline, law is anchored on precedents, meaning how earlier cases were decided and how issues were resolved in previous cases. This is because lawyers are traditionally taught to look at what the law is and not what it should be. The main thrust in law schools is adherence to precedents rather than how justice can be achieved better by what the law should be. Ph.D. graduates with a good background in law, and using broader knowledge of the tools of social science, can employ this approach more effectively.

Wexler (1990, p. 198) observes that "social science data" is relevant to the "resolution of legal and public policy disputes." However, since law training primarily focuses on doctrinal law and repetitive analysis of case doctrine, law students are not taught to question its relevance for public policy (Berard, 2009; Bradney, 1998; Rubin, 2007; Wexler, 1990). Law schools train their students to perceive certain sources of law 
and legal authorities as authoritative. They are taught the doctrine of stare decisis, which basically means "let the decision stand." There is justification for in a field where justice should be predictable and consequences follow a punishable act. As a tool for reform based on current research, however, this orientation falls short of being causative or effective. Students are thus not trained to question or criticize legal authorities. Instead, they learn what the law is, spending "much of their time examining legal texts and trying to make sense of them" to be able to apply them to relevant factual situations (Samuel, 2008, p. 309). This approach is certainly necessary to prepare the student for eventual legal practice after law school. It detracts, however, from the reality of legal practice not as an isolated field requiring simply route memory and understanding of black letter law but as a process ensconced in a broader criminal justice system.

Non-law students, including those in criminal justice and criminology, are better prepared to assess the relevance of the social sciences in helping shape the law and the legal system (Wexler, 1990). By approaching law as a social science, the usefulness of court decisions and legislation can be viewed from an external and empirical perspective (Samuel, 2008), with more enlightened results. Posner (1998, p. 6) writes about economists who analyze law by "constructing models of legal rules and evaluating their potential effect on overall social welfare." Social science research in law affords opportunities to challenge doctrine, among others, by evaluating and questioning how judges actually decide cases (Frank, 1931).

In the discipline of criminal justice and criminology, continuing studies of either the black letter law or even more far-reaching socio-legal studies that examine law and its social implications can reveal its relevance or irrelevance, its benefits or costs, and its 
strengths or weaknesses relating to what law seeks to achieve. Studies that focus on inconsistency among court decisions on a particular issue, for example, can reveal whether or not a specific decision is worth re-examining. For example, research by Nolasco, del Carmen, and Vaughn (2010) showed that the U.S. Supreme Court's modification of the good faith exception of the exclusionary rule in Herring v. United States (2009) (to apply to law enforcement officers who relied on errors or mistakes of other law enforcement personnel as long as these errors were merely negligent and isolated, instead of systemic, recurring, and/or deliberate) resulted in a divergence and inconsistencies in its application among federal district and circuit courts and thus detract from the strength and value of the exclusionary rule as an evidentiary remedy in criminal procedure.

Examining its social impact and ramifications outside of black letter law can also lead to reform and improvements in the law and the criminal justice system. Studies on access to legal services (Bewicke, 2011; Morris, 2013; Rogerson, 2013), differential treatment of white collar defendants versus street criminals (Guidice, 2011; Morris \& Sayed, 2013; Payne, Blowers, \& Jarvis, 2012; Payne, Dabney, Ekhomu, 2013; Perri, 2011; Richman, 2013), and representation and treatment of women and minorities in the criminal justice system (Bright, Kohl, \& Jonson-Reid, 2014; Klein \& Kress, 1976; Nolasco \& Vaughn, 2010; Sangoi \& Goshin, 2014) are helpful in identifying the deficiencies of the criminal justice system and crafting reform policies.

\section{PROPOSITIONS 5: COURSES IN LAW IN CJ PROGRAMS ARE ARGUABLY BETTER TAUGHT FROM A BROADER PERSPECTIVE BY PH.D. GRADUATES WHO HAVE LEGAL COMPETENCY. Ph.D. graduates with legal competency are more broadly trained in law-}


related issues affecting the discipline than those who do not have a good background in law or those whose approach, by virtue of their training, is essentially advocacy oriented. Their socio-legal perspective of any law-related issue relevant to the discipline enables them to teach law as part of the overall CJ discipline instead of the more narrow focus that will likely be used by law practitioners. Ph.D. graduates can and should be scholars; law graduates are trained to be good practitioners. An assumption is that most law courses in CJ programs, particularly on the undergraduate level, are taught by lawyers and practitioners serving as adjuncts (Engvall, 2007). This is particularly true in small CJ programs where law courses are usually delegated to practitioners because they are the ones who know the law. While competent, the focus in practitioner-taught courses is more likely on the narrower aspects of law as experienced in legal practice. Full-time Ph.D. faculty can teach law from a broader perspective, integrating law with other findings in social science and criminology. Conversely, criminal justice departments are reluctant for Ph.D. graduates to teach law because it is viewed as a specialized field which can and should be taught only by lawyers. In the course of their career, Ph.D. graduates will likely be asked to teach law, particularly in small departments. Developing legal competency through adequate training in law better prepares and enhances the marketability of Ph.D. graduates who are on the job market or are already part of academe. In the process, law is then taught from a broader perspective. An adequate knowledge of law, however, is crucial in this process. 


\section{CONCLUSION}

Robert Quinney (1970, p. 3) is right when decades ago, he said: "There is no crime without some form of declaration." In any civilized country in the world today, crime exists because there is a law prohibiting and punishing the act or omission. Without law declaring an act punishable and how, there is no crime-punishment then can become arbitrary and capricious. Law is central to our concept of crime and its punishment - and it should be if a country is to judge and punish those who commit crimes with fairness and due process. Those who teach criminology and criminal justice must have a good knowledge of and about law for the discipline and the public to be best served. How this is achieved needs further study, but one of its essential ingredients is legal competency among those who teach and conduct research that helps determine its future.

The social sciences enable the general public to better understand the social context and implications of any means of social control. The discipline of criminal justice and criminology, by incorporating law courses in its curriculum, benefits from a fuller understanding of all aspects of the criminal justice system and by viewing crime or delinquency as a social behavior. By incorporating law courses as part of the curriculum, and recognizing the impact of these courses, the discipline stands to enrich the field of law in criminal justice and helps dispense justice. The discipline's need for law trained professionals with Ph.D. credentials is best met by requiring law courses in the curriculum. This is particularly true for those who teach in the discipline.

Recognizing the benefits of interdisciplinary studies in other academic areas, including law, other programs have initiated interdisciplinary and multidisciplinary research in their fields. This growing trend recognizes the value of a multi-dimensional 
approach to the study of any social subject, including law and the criminal justice system. Criminal justice and criminology can add to our understanding of crime and the justice system by institutionalizing law courses that help students better understand when crime occurs and its legal consequences. Law is the ultimate and most coercive means of governmental control in the United States. In a real sense, without law there is no criminal justice; without law criminology can be a tool for explaining criminal behavior, but cannot legally prescribe ways of punishing an offender. It is important that those who administer criminal justice and criminology know something more than "a little something" about criminal justice law but it is even more important that criminal justice laws be understood by those who teach and wish to improve it.

\section{REFERENCES}

ACJS Executive Board. (2014a). Academy of Criminal Justice Sciences Certification Standards for College/University Criminal Justice/Criminology Baccalaureate Degree Programs. Retrieved from http://www.acjs.org/uploads/file/ACJSCertificationStandards-Baccalaureate.pdf

ACJS Executive Board. (2014b). Academy of Criminal Justice Sciences Certification Standards for College/University Criminal Justice/Criminology Master's Degree Programs. Retrieved from http://www.acjs.org/uploads/file/ACJSCertificationStandards-Masters.pdf

Bartie, S. (2010). The lingering core of legal scholarship. Legal Studies, 30, 345-369. 
Banakar, R. (2011). Review essay: Having one's cake and eating it: The paradox of contextualization in socio-legal research. International Journal of Law in Context, 7, 487-503.

Berard, T. (2009). The relevance of the social sciences for legal education. Legal Education Review, 19, 189-215.

Bewicke, A. (2011). Asian developments in access to counsel: A comparative study. Northwest Journal of International Human Rights, 10, 27-53.

Birks, P. (1998). The academic and the practitioner. Legal Studies, 18, 397-414.

Bradney, A. (1998). Law as a parasitic discipline. Journal of Law and Society, 25, 71-84.

Bright, C., Kohl, P., \& Jonson-Reid, M. (2014). Females in the juvenile justice system: Who are they and how do they fare? Crime \& Delinquency, 60, 106-125.

Bybee, K. (2004). The liberal arts, legal scholarship, and the democratic critique of judicial power. In A. Sarat (Ed), Law in the liberal arts (pp. 41-68). Ithaca, NY: Cornell University Press.

Cartan, G., \& Vilkinas, T. (1990). Legal literacy for managers: The role of the educator. The Law Teacher, 24, 246-257.

Chase, A. (1979). The birth of the modern law school. American Journal of Legal History, 23, 329-348.

Chemerinsky, E. (2008). Radical proposals to reform legal pedagogy: Rethinking legal education. Harvard Civil Rights- Civil Liberties Law Review, 43, 595-598.

Clear, T. R. (2001). Has academic criminal justice come of age? Justice Quarterly, 18, 709-726. 
Conrad, J. P., \& Myren, R. A. (1979). Two views of criminology and criminal justice:

Definitions, trends, and the future. Chicago, IL: Joint Commission on Criminology and Criminal Justice Education and Standards.

Cotterrell, R. (1995). Law's Community: Legal Theory in Sociological Perspective. Oxford: Clarendon Press.

Cownie, F. (2004). Legal academics: Culture and identities. Oxford: Hart Publishing.

Cross, F., \& Tiller, E. (1998). Judicial partisanship and obedience to legal doctrine: Whistleblowing on the federal courts of appeals. Yale Law Journal, 107, 2155-2176.

DiCristina, B. (1997). The quantitative emphasis in criminal justice education. Journal of Criminal Justice Education, 8, 181-199.

Duxbury, N. (2003). A century of legal studies. In P. Cane \& M. Tushnet (Eds), The Oxford handbook of legal studies (pp. 950-974). Oxford, UK: Oxford University Press.

Engvall, R. P. (2007). Is it really just a J.D.? ACJS Today, 32(1), 1, 5-6.

Eisenmann, C. (1973). The university teaching of the social sciences: Law. Lanham, MD: Bernan Associates.

Eitle, D., Niedrist, F., Eitle, T. (2014). Gender, Race, and Delinquent Behavior: An Extension of Power-Control Theory to American Indian Adolescents. Deviant Behavior, 35, 1023-1042.

Epstein, L., \& King, G. (2002). The rules of inference. University of Chicago Law Review, 69, 1-93.

Epstein, L., Martin, A., \& Schneider, M. (2006). On the effective communication of the results of empirical studies part 1. Vanderbilt Law Review, 59, 1811-1871. 
Epstein, L., Martin, A., \& Boyd, C. (2007). On the effective communication of the results of empirical studies part 2. Vanderbilt Law Review, 60, 801-846.

Frank, J. (1931). Are judges human? University of Pennsylvania Law Review, 80, 17-53.

Garland, D. (2013). The 2012 Sutherland address: Penality and the penal state. Criminology, 51, 475-517.

Greene, J. R., Bynum, T. S., \& Webb, V. J. (1982). Crime related education: Faculty roles, values and expectations. Chicago, IL: Joint Commission on Criminology and Criminal Justice Education and Standards, 1982.

Grey, T. (1983). Langdell's orthodoxy. University of Pittsburg Law Review, 45, 1-53.

Grunwald, B. (2013). Suboptimal social science and judicial precedent. University of Pennsylvania Law Review, 161, 1409-1443.

Guidice, L. (2011). Regulating corruption: Analyzing uncertainty in current foreign corrupt practices act enforcement. Boston University Law Review, 91, 347-378.

Harris, P. (1986). Curriculum development in legal studies. The Law Teacher, 20, 110-123.

Hemmens, C. (2008). Waist deep in the big muddy: The J.D./Ph.D. debate in criminal justice education. Journal of Criminal Justice Education, 19, 19-29.

Hepple, B. (1996). The renewal of the liberal law degree. Cambridge Law Journal, 55, 470-487.

Jennings, W., Higgins, G., Akers, R., Khey, D., \& Dobrow, J. (2013). Examining the Influence of Delinquent Peer Association on the Stability of Self-Control in Late Childhood and Early Adolescence: Toward an Integrated Theoretical Model. Deviant Behavior, 34(5), 407-422.

Johnstone, R. (1992). Rethinking the teaching of law. Legal Education Review, 3, 16-59. 
Kahan, D., Jenkins-Smith, H., \& Braman, D. (2011). Cultural cognition of scientific consensus. Journal of Risk Research, 14, 147-174.

Kelman, M. (2003). Law and behavioral science: Conceptual overviews. Northwestern Law Review, 97, 1347-1392.

Kennedy, D., \& Fisher, W. (2006). The canon of american legal thought. Princeton: Princeton University Press.

Klein, D., \& Kress, J. (1976). Any woman's blues: A critical overview of women, crime, and the criminal justice system. Crime and Social Justice, 5, 34-49.

Korobkin, R. (2014). Comparative effectiveness research as choice architecture: the behavioral law and economics solution to the health care cost crisis. Michigan Law Review, 112, 523-574.

Landes, W., \& Posner, R. (2009). Rational judicial behavior: A statistical study. Journal of Legal Analysis, 1, 775-831.

Lawless, R., Robbennolt, J., \& Ulen, T. (2009). Empirical methods in law. New York: Aspen Publishers.

Leighton, P., Mortimer, T., \& Whatley, N. (1995). Law teachers: lawyers or academics? London: Cavendish Publishing.

Leonard, T. (2002). Reflection on rules in science: An invisible-hand perspective. Journal of Economic Methodology, 9, 141-168.

Macey, J. (1997). Law and the social sciences. Harvard Journal of Law \& Public Policy, 21, 171-178.

Madden, R., \& Wayne, R. (2003). Social work and the law: A therapeutic jurisprudence perspective. Social Work, 48, 338-347 
Manning, B. (1969). American legal education: Evolution and mutation- three models. Stanford, CA: Stanford Law School.

Marciano, A., \& Ramello, G. (2014). Consent, choice, and guido calabresi's heterodox economic analysis of law. Law \& Contemporary Problems, 77, 98-116.

Meares, T. (2002). Three objections to the use of empiricism in criminal law and procedure and three answers. University of Illinois Law Review, 2002, 851-874.

Monahan, J., \& Walker, L. (1991). Judicial use of social science research. Law and Human Behavior, 15, 571-584.

Monahan, J., \& Walker, L. (1986). Social authority: Obtaining, evaluating, and establishing social science in law. University of Pennsylavania Law Review, 134, 477-517.

Morn, F. T. (1980). Academic disciplines and debates: An essay on criminal justice and criminology as professions in higher education. Chicago, IL: Joint Commission on Criminology and Criminal Justice Education and Standards.

Morris, P. (2013). Mediation, the legal aid, sentencing and punishment of offenders act of 2012 and the mediation information assessment meeting. Journal of Social Welfare and Family Law, 35, 445-457.

Morris, R. (2005). Globalizing and de-hermeticizing legal education. Brigham Young University Education and Law Journal, 53, 53-81.

Morris, R., \& Sayed, S. (2013). The development of self-reported white-collar offending. Journal of Contemporary Criminal Justice, 29, 369-384.

Myers, L. (2007). The search for the criminal justice educator. A response to Robert Engvall's article, "is it really just a J.D.?" ACJS Today, 32, 1, 5-6. 
Newton, N. \& Bussey, K. (2012). The age of reason: An examination of psychosocial factors involved in delinquent behaviour. Legal \& Criminological Psychology, 17, 75-88.

Nolasco, C., del Carmen, R.V., \& Vaughn, M.S. (2010). What Herring hath wrought: An analysis of post-Herring cases in the federal courts. American Journal of Criminal Law, 38, 221-261.

Nolasco, C., \& Vaughn, M.S. (2010). Judicial scrutiny of gender-based employment practices in criminal justice agencies. Journal of Criminal Justice, 39, 106-119.

Nolasco, C., Vaughn, M.S. \& del Carmen, R. V. (2010). Toward a new methodology for legal research in criminal justice. Journal of Criminal Justice Education, 21, 1-23.

Packer, H., \& Ehrlich, T. (1972). New directions in legal education. New York: McGraw-Hill Book Company.

Payne, B., Blowers, A., \& Jarvis, D. (2012). The neglect of elder neglect as a white-collar crime: Distinguishing patient neglect from physical abuse and the criminal justice system's response. Justice Quarterly, 29, 448-468.

Payne, B., Dabney, D., \& Ekhomu, J. (2013). Sentencing disparity among upper and lower class health care professionals convicted of misconduct. Criminal Justice Policy Review, 24, 353-369.

Perino, M. (2006). Law, ideology, and strategy in judicial decision making: Evidence from securities fraud actions. Journal of Empirical Legal Studies, 3, 497-524.

Perri, F. (2011). White-collar criminals: The 'kinder, gentler' offender? Journal of Investigative Psychology \& Offender Profiling, 8, 217-241. 
Portnoy, J., Raine, A., Chen, F., Pardini, D., Loeber, R., \& Jennings, J. (2014). Heart rate and antisocial behavior: the mediating role of impulsive sensation seeking. Criminology, 52, 292-311.

Posner, R. (1998). Law and literature. Cambridge, MA: Harvard University Press.

Preston-Shoot, M., \& McKimm, J. (2011). Towards effective outcomes in teaching, learning, and assessment of law in medical education. Medical Education, 45, 339-346.

Quinney, R. (1970). The problem of crime. New York: Dodd, Mead \& Company, Inc.

Revesz, R. (1997). Environmental regulation, ideology, and the D.C. circuit. Virginia Law Review, 83, 1717-1772.

Richman, D. (2013). Federal white collar sentencing in the United States: A work in progress. Law \& Contemporary Problems, 76, 53-73.

Ridley, A. (1994). Legal skills for non-law students: Added value or irrelevant diversion? The Law Teacher, 28, 281-291.

Rogerson, S. (2013). Lack of detained parents' access to the family justice system and the unjust severance of the parent-child relationship. Family Law Quarterly, 47, 141172.

Rubin, E. (2007). What's wrong with Langdell's method and what to do about it. Vanderbilt Law Review, 60, 609-665.

Samuel, G. (2008). Is law really a social science? A view from comparative law. Cambridge Law Journal, 67, 288-321.

Samuel, G. (2012). Is legal knowledge cumulative? Legal Studies, 32, 448-479.

Sangoi, L., \& Goshin, L. (2014). Women and girls' experiences before, during, and after incarceration: a narrative of gender-based violence, and an analysis of the criminal 
justice laws and policies that perpetuate this narrative. UCLA Women's Law Journal, 20, 137-168.

Schluchter, W. (2002). The sociology of law as an empirical theory of validity. Journal of Classical Sociology, 2, 257-280.

Schweber, H. (1999). The 'science' of legal science: The model of natural sciences in nineteenth century American legal education. Law and History Review, 17, 421-466.

Shaffer, G., \& Ginsburg, T. (2012). The empirical turn in international legal scholarship. American Journal of International Law, 106, 1-46.

Siems, M. (2011). Measuring the immeasurable: How to turn law into numbers. In M. Faure \& J. Smits (Eds.), Does law matter? On law and economic growth. Cambridge, MA: Intersentia.

Siems, M., \& MacSithigh, D. (2012). Mapping legal research. Cambridge Law Journal, 71, 651-676.

Simpson, A. E. (1979). Accreditation and its significance for programs of higher education in criminology and criminal justice: A review of the literature. Chicago, IL: Joint Commission on Criminology and Criminal Justice Education and Standards.

Sisk, G., \& Heise, M. (2005). Judges and ideology: Public and academic debates about statistical measures. Northwestern University Law Review, 99, 743-803.

Skwarok, L. (1995). Business law for non-lawyers: Setting the stage for teaching, learning and assessment at Hong Kong Polytechnic University. The Law Teacher, 29, 189-212.

Steinmetz, K. F., Schaefer, B. P., del Carmen, R. V., \& Hemmens, C. (2014, Online First). Assessing the boundaries between criminal justice and criminology. Criminal Justice Review. 
Stevens, R. B. (1983). Law school: Legal education in america from the 1850s to the 1980 s. Clark, NJ: The Lawbook Exchange, Ltd.

Sunstein, C., Schkade, D., Ellman, L., \& Sawicki, A. (2006). Are judges political? An empirical analysis of the federal judiciary. Washington, DC: Brookings Institution Press.

Sutherland, E. (1924). Principles of Criminology. Philadelphia, PA: J. B. Lippincott Company.

Tait, D., \& De Young, R. (2000). Displaying the law: A cross-disciplinary learning experiment using the internet and multimedia technology. International Review of Law Computers \& Technology, 14, 191-204.

Timasheff, N. (1937). What is "sociology of law"? American Journal of Sociology, 43, 225235.

Trubek, D., \& Plager, S. (1985). The place of law and social science in the structure of legal education. Journal of Legal Education, 35, 483-488.

Walker, L., \& Monahan, J. (1987). Social frameworks: A new use of social science in law. Virginia Law Review, 73, 559-598.

Wexler, D. (1990). Training in law and behavioral sciences: Issues from a legal educator's perspective. Behavioral Sciences and the Law, 8, 197-204.

Wilkins, D. (1999). The professional responsibility of professional schools to study and teach about the profession. Journal of Legal Education, 49, 76-95.

Worrall, J. (2000). In defense of the "quantoids": More on the reasons for the quantitative emphasis in criminal justice education and research. Journal of Criminal Justice Education, 11, 353-361. 
Wrede, C., \& Featherstone, R. (2012). Striking out on its own: The divergence of criminology and criminal justice from sociology. Journal of Criminal Justice Education, 23, 103-125.

Zalman, M. (1981). A heuristic model of criminology and criminal justice. Chicago, IL: Joint Commission on Criminology and Criminal Justice Education and Standards.

\section{CASES CITED}

Chevron U.S.A. Inc. v. Natural Res. Def. Council, Inc., 467 U.S. 837 (1984).

Herring v. United States, 555 U.S. 135(2009).

State v. Chapple, 660 P.2d 1208 (Ariz. 1983). 